\title{
PENGEMBANGAN POTENSI KARANG TARUNA MELALUI KEMANDIRIAN WIRAUSAHA BERBASIS POTENSI LOKAL DI KABUPATEN GRESIK
}

\author{
Moh. Agung Surianto ${ }^{1 *}$ dan Rahmat Agus Santoso ${ }^{1}$ \\ ${ }^{1}$ Dosen Program Studi Manajemen Fakultas Ekonomi \\ Universitas Muhammadiyah Gresik \\ *Penulis korespondensi; Email: cakagung27@gmail.com
}

\begin{abstract}
Abstrak: Kabupaten Gresik sebagai salah satu dari 38 daerah kabupaten dan kota yang ada di Jawa Timur memiliki kompleksitas permasalahan pembangunan kepemudaan, khususnya dalam hal jumlah pengangguran. Subyek pada program pengabdian masyarakat saat ini adalah Karang Taruna Desa Glanggang dan Karang Taruna Gadukan Kabupaten Gresik. Motivasi berorganisasi yang positif dari pemuda desa tersebut menjadi penting diperhatikan dan menjadi poin penting bagi pengembangan pemuda menjadi wirausaha dengan menciptakan nilai tambah berbasis potensi lokal desa. Kegiatan yang telah dilakukan adalah workshop membangun mindset wirausaha, pelatihan pengolahan ikan, pemasaran dan tertib administrasi keuangan serta pendampingan. Luaran yang dihasilkan dalam program pengabdian ini adalah; a. munculnya keberanian memulai berwirausaha b. perijinan P-IRT di Dinas Kesehatan Kabupaten Gresik untuk produk olahan ikan.
\end{abstract}

Kata kunci: Wirausaha; karang taruna; potensi lokal

\begin{abstract}
Gresik as one of the 38 districts and cities in East Java has the complexity of the problems of youth development, especially the number of unemployment. The subject for this community service program covers Karang Taruna Glanggang and karang Taruna Gadukan in the area of Gresik Regency. The youth has positive motivation in joining organization and became important point to create the youth to have ability to be an entrepreneur by local potention from the local village. Several programs were implemented in the form of enhancing youth entrepreneur mindset, training of fish processing, marketing and financial administration also consultancy program. The outcome of this program;a. The emerging of start-up business b. PIRT licensing in Gresik District Health Office for processed fish products.
\end{abstract}

Keywords: Entrepreneurship; youth; local potention.

\section{PENDAHULUAN}

Data BPS juga menunjukkan bahwa 53 persen pengangguran berusia di bawah 25 tahun dan mayoritas penganggur ini adalah pengangguran terdidik karena 74,5 persen berpendidikan SMA atau lebih tinggi. Bahkan, persoalan pengangguran di Indonesia sudah menjadi isu internasional karena 5 persen (hampir 10 juta) dari 200 juta pengangguran di seluruh dunia berada di Tanah Air (http://bisnismanajemen.co.id: 24 Maret 2013).

Keberhasilan pembangunan pemuda sebagai sumber daya manusia (SDM) yang berkualitas dan memiliki keunggulan daya saing, merupakan salah satu kunci untuk membuka peluang bagi keberhasilan di berbagai sektor pembangunan lainnya. Oleh karena itu, pembangunan kepemudaan di- anggap sebagai salah satu program yang tidak dapat diabaikan dalam menyiapkan wajah bangsa di masa depan.

Kabupaten Gresik sebagai salah satu dari 38 daerah kabupaten dan kota yang ada di Jawa Timur juga memiliki kompleksitas permasalahan pembangunan kepemudaan, khususnya dalam hal jumlah penganggurann yang terus bertambah sebagaimana Gambar 1.

Program pengabdian masyarakat yang dilakukan mengambil subyek pengabdian terhadap pemuda karang taruna di Desa Glanggang dan Gadukan Kecamatan Duduk Sampeyan Kabupaten Gresik. Unsur pemuda menjadi penting mengingat karang taruna merupakan organisasi yang langsung bersentuhan dengan para pemuda di tingkat desa. 


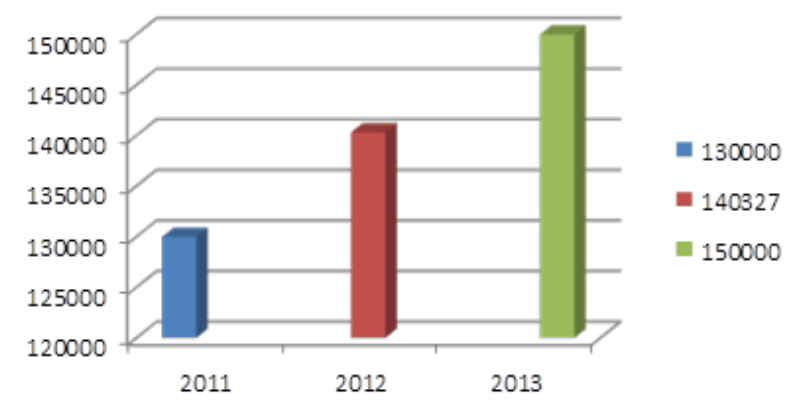

Sumber: Dinas Tenaga Kerja dan Transmigrasi (Disnakertrans) Kabupaten Gresik: 6 September 2013 http://www. beritametro.co.id.

Gambar 1. Angka Pengangguran Di Kabupaten Gresik Tahun 2011, 2012 dan 2013

Sehingga program ini diharapkan nantinya akan menjadi stimulan bagi karang taruna lain guna menjadi seorang wirausaha yang mampu menciptakan nilai tambah potensi desanya.

Adapun luaran yang ingin dihasilkan dalam program pengabdian masyarakat ini adalah;

1. Muncul wirausaha muda dari anggota/pengurus karang taruna Gadukan dan Glanggang sebagai bentuk pelopor penciptaan nilai tambah dari produk yang dihasilkan oleh para petani tambak.

2. Proses perijinan P-IRT dari Dinas Kesehatan Kabupaten Gresik atas produk olahan ikan yang dibuat.

\section{ANALISIS SITUASI}

Data penerimaan devisa dari TKI (remitansi) yang masuk di Kabupaten Gresik tahun 2012, menunjukkan bahwa Gresik menjadi daerah penerima remitansi terbesar kedua di Jatim dan mengalami penurunan yang tajam pada tahun 2013 sebagaimana Tabel 1.

Tabel 1. Perbandingan Remitansi Tahun 2012 dan 2013

\begin{tabular}{llcc}
\hline \multicolumn{1}{c}{ Wilayah } & Remitasi 2012 & Remitasi 2013 & \% Penurunan \\
\hline Malang Raya & Rp 205,489 miliar & Rp 162,562 miliar & $20,89 \%$ \\
Gresik & Rp 146,787 miliar & Rp 51,9 miliar & $64,66 \%$ \\
Sidoarjo & Rp 101,999 miliar & Rp 21,398 miliar & $79,02 \%$ \\
\hline Sumber: Deputi Kepala Perwakilan Bidang Sistem Pembayaran dan \\
Maajemen Intern Bank Indonesia (BI) Perwakilan & Malang: 2 \\
Pebruari 2014: http://www.antarajatim.com
\end{tabular}

Kondisi ini menjadi menarik (kontras), mengingat Kabupaten Gresik dengan jumlah penduduk 1.307.995 orang (Gresik Dalam Angka: 2013) merupakan kota industri yang menjadi buffer (penyangga) kota Surabaya memiliki posisi strategis sebagai destinasi investasi industri dan perdagangan, sehingga berimplikasi terhadap multiplier efek yang sangat positif dan potensial dalam pengembangan kewirausahaan.
Data lain yang menjadi faktor penting pendorong guna mengembangkan program kewirausahaan pemuda di Kabupaten Gresik adalah kemampuan daya beli di Kabupaten Gresik yang cukup tinggi. lnformasi tersebut merujuk pada Peraturan Gubernur Jatim Nomor 78 Tahun 2013 tentang Upah Minimum Kabupaten/Kota di Jawa Timur 2014 tertanggal 20 November 2013 diputuskan bahwa UMK Kabupaten Gresik tahun 2014 sebesar Rp. 2.195.000, berada pada peringkat nomor 2 tertinggi di Jatim dibawah UMK kota Surabaya.

Profil Desa Glanggang sebagai setting kegiatan, merupakan sebuah desa yang menjadi bagian dari Kecamatan Duduk Sampeyan Kabupaten Gresik, dengan luas 132,85 hektar. Mayoritas areal lahannya $(73,2 \%)$ berupa tambak; yakni seluas 97,33 hektare dan sisanya berupa tanah kering dan pekarangan (Kecamatan Duduk Sampeyan Dalam Angka: 2012) Desa Glanggang mayoritas penduduknya berprofesi sebagai petani tambak dan hasilnya langsung dijual ke tengkulak sebagaimana profil secara umum Kecamatan Duduksampeyan sebagaimana Gambar 2

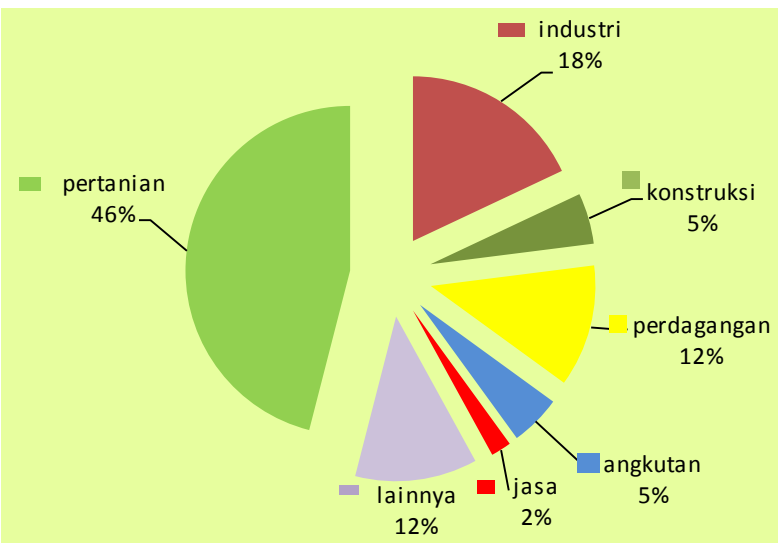

Sumber: Kecamatan Duduksampeyan Dalam Angka: 2012

Gambar 2. Penduduk yang Bekerja Berdasarkan Lapangan Usaha

Permasalahan prioritas mitra yang berdasarkan hasil observasi, wawancara dan koordinasi dengan para pengurus karang taruna yaitu rendahnya motivasi berwirausaha dari kalangan pemuda yang ada di desa Glanggang, dan para petani belum berpikir menciptakan nilai tambah atas produk yang dihasilkan.

\section{METODE PELAKSANAAN}

Metode pelaksanaan program pengabdian masyarakat yang dilakukan dalam tiga tahap utama: pertama; tahap observasi dan wawancara, kedua; workshop kewirausahaan dan pelatihan life skill, ketiga; tahap pendampingan. Berikut deskripsi tahapan program pengabdian yang telah dilakukan seperti pada Gambar 3. 


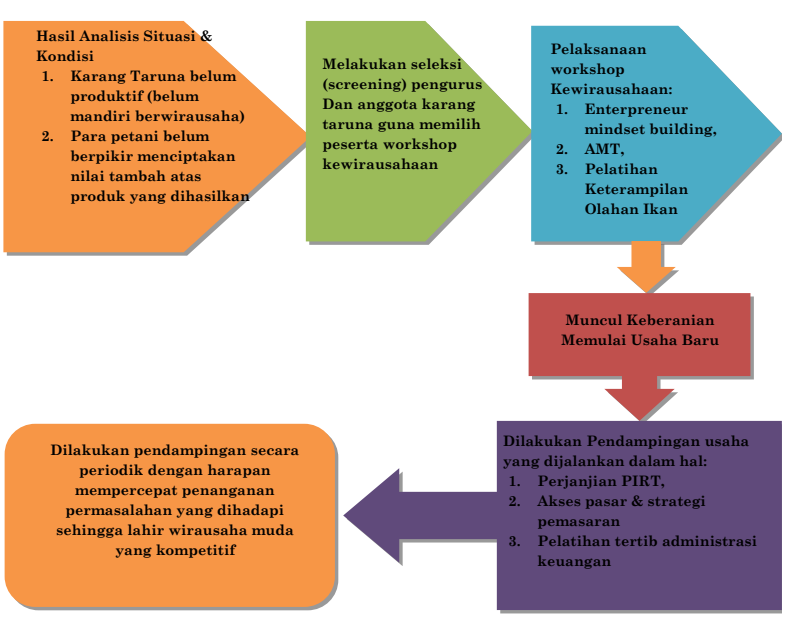

Gambar 3. Tahapan Program Pengabdian

\section{PELAKSANAAN KEGIATAN}

Kegiatan program pengabdian masyarakat ini dilaksanakan selama delapan bulan sejak April sampai dengan November 2015. Kegiatan tahap awal dimulai dengan melakukan koordinasi dengan jajaran pengurus Karang Taruna dan pemerintah desa Glanggang.

Tahap koordinasi dilakukan dengan cara observasi dan wawancara langsung ke lokasi kantor karang taruna dan kantor Desa Glanggang. Tahap awal ini menjadi penting mengingat jumlah anggota kedua karang taruna cukup banyak, akan tetapi kuota peserta terbatas hanya 10 orang orang. Oleh sebab itu dilakukan dilakukan wawancara mendalam agar diperoleh peserta yang benar-benar memiliki motivasi dasar berwirausaha.

Berikut daftar 10 orang pengurus karang taruna yang menjadi peserta program kewirausahaan dengan komposisi 5 orang dari Gadukan dan 5 orang dari Glanggang;

Tabel 2. Profil Peserta Workshop

\begin{tabular}{lll}
\hline No Nama & Tempat Tanggal lahir \\
\hline 1 & Fajar R Fanani & Magetan, 20 April 1989 \\
2 & Muhibbi Al Hasan & Gresik, 9 April 1996 \\
3 & Viki Bagus p & Gresik,25 Januari 1992 \\
4 & Muhammad Anas & Gresik, 30 Juni 1993 \\
5 & Ilham Fatih & Gresik, 5 Mei 1996 \\
6 & Muchammad Bayu Setiyono & Gresik, 3 Oktober 1997 \\
7 & Hari Sutriadi & Gresik, 12 desember \\
& & 1988 \\
8 & Khoirun Ni'am & Gresik, 28 April 1996 \\
9 & As'ad Kurniawan & Gresik, 25 Juni 1994 \\
10 & Setia Erdiansyah & Surabaya, 09 September \\
& & 1987 \\
\hline
\end{tabular}

Merujuk tabel diatas, menunjukkan bahwa usia peserta workshop diantara rentang 19 tahun s/d 28 tahun. Hal ini mengindikasikan rata-rata anggota karang taruna adalah masuk ketageri usia produktif dan penting mengikuti program kewirausahaan yang dilakukan agar terjadi re-orientasi peserta dari yang sebelumnya lebih dominan berkeinginan sebagai pekerja bergeser menjadi wirausaha.

Pelaksanaan program pengabdian tahap kedua diawali dengan melaksanakan kegiatan workshop selama 2 (dua) hari di Universitas Muhammadiyah Gresik pada tanggal 15 dan 16 Juni 2015. Materi workshop; mendorong motivasi berprestasi dan membangun mindset wirausaha diikuti oleh para peserta dengan antusias dan sungguh-sungguh. Semua peserta hadir tepat waktu dan mengikuti jadwal kegiatan secara tertib.

Respon positif para peserta dapat dilihat selain dari kehadiran dan keseriusan ketika acara berlangsung, juga dapat dilihat pada saat sesi tanya jawab. Para peserta aktif mengajukan pertanyaan, membahas kasus serta memiliki motivasi yang tinggi ketika melakukan presentasi hasil diskusi kelompok yang telah mereka lakukan. Berikut sebagian gambaran kegiatan workshop yang telah dilakukan;
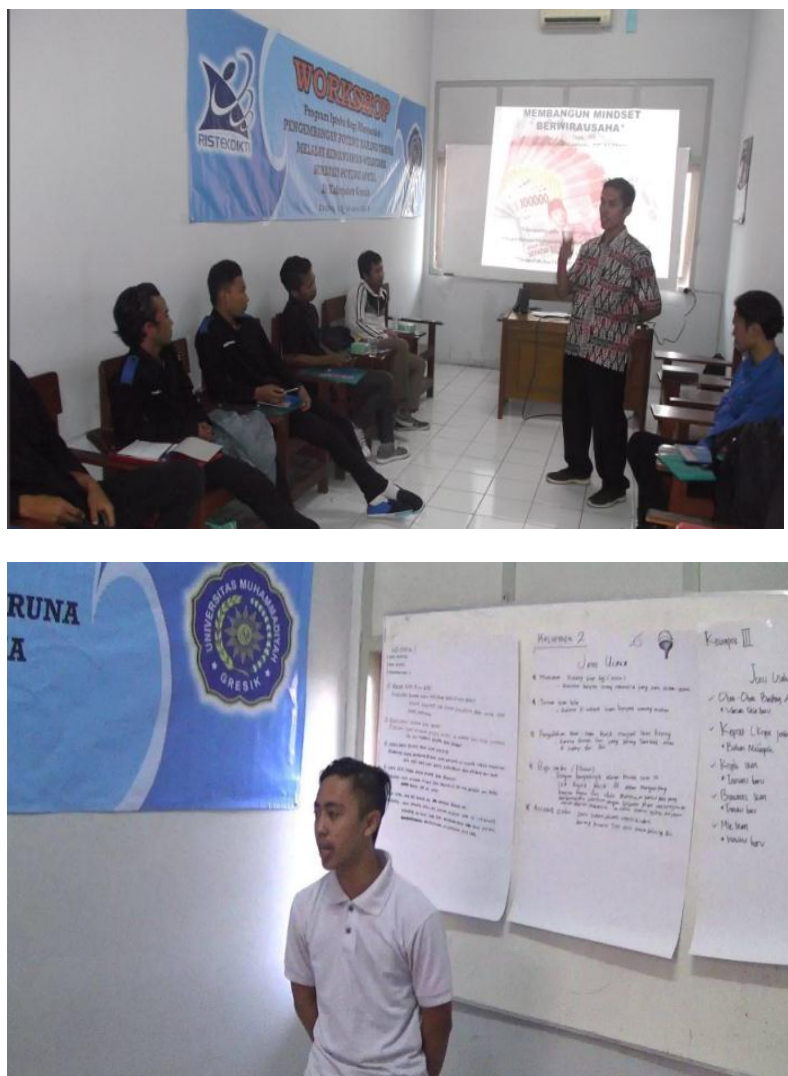

Gambar 4. Suasana Workshop

Kegiatan lanjutan yang dilaksanakan setelah workshop adalah pelatihan pembuatan olahan ikan (abon), adalah pelatihan akses pasar dan pemasaran dan pembukuan untuk UMKM. Dasar pemikir- 
an pelaksanaan pelatihan abon ikan ini berasal dari potensi hasil tambak ikan yang melimpah di Desa Glanggang, mengingat profesi mayoritas masyarakat adalah petani tambak, dan hasil panen yang ada belum dilakukan proses pengolahan lebih lanjut guna meningkatkan nilai tambah produk. Semua hasil panen tambak ikan langsung dijual ke pengepul atau ke pasar ikan.

Tanggapan peserta karang taruna dan Kepala Desa sangat positif dalam sesi pelatihan yang langsung dilaksanakan di Kantor Balai Desa Glanggang sebagaimana Gambar 5.
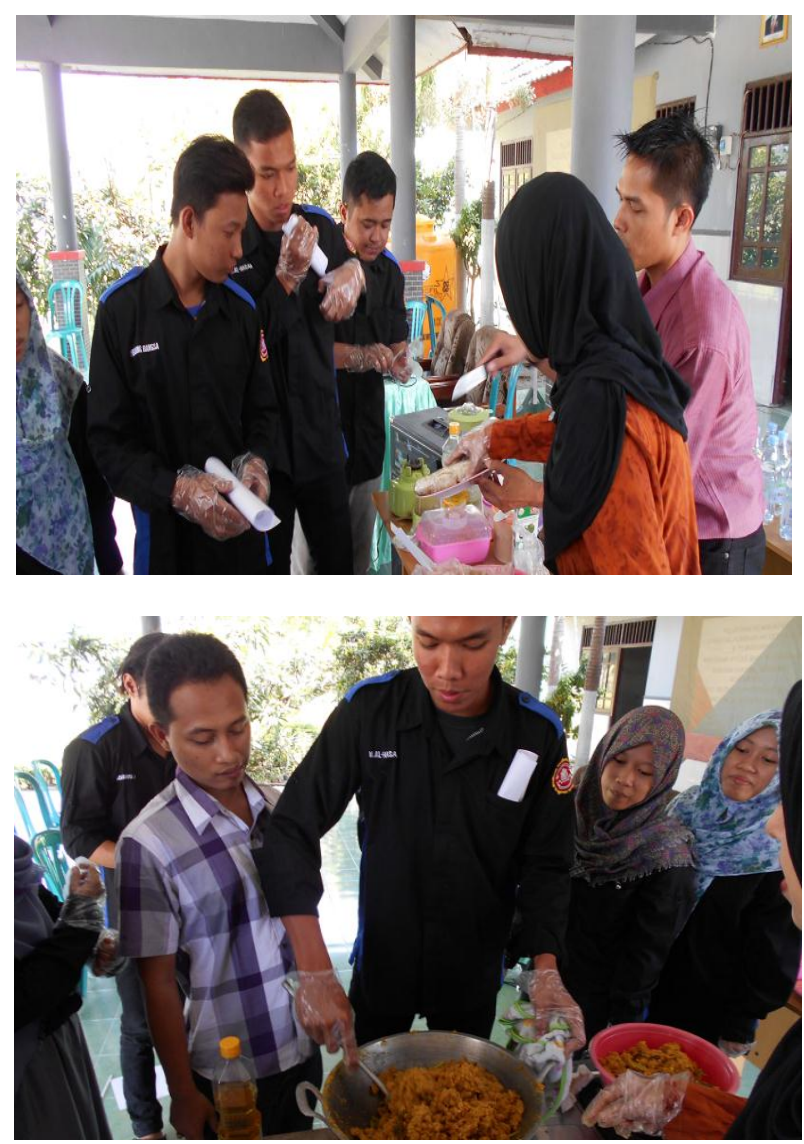

Gambar 5. Pelatihan Pembuatan Olahan (Abon) Ikan

Setelah pelatihan pembuatan abon ikan selesai dilaksanakan, pelatihan berikutnya adalah pelatihan akses pasar dan strategi pemasaran. Pelatihan ini penting dengan tujuan peserta mampu merumuskan dan memutuskan target konsumen dan jenis produk yang akan dibuat serta strategi penjualan yang dilakukan. Respon peserta sangat dinamis terlihat dalam sesi tanya jawab pelatihan ini.

Pelatihan berikutnya adalah tertib administrasi keuangan. Mengingat peserta pelatihan dalam program ini masih sangat awam tentang pengetahuan Manajemen Keuangan, maka pelatihan dilakukan dengan penekanan agar peserta ketika memutus- kan mengembangkan usaha, mampu mempraktekkan disiplin pencatatan dalam transaksi keuangan yang dilakukan. Hal ini penting mengingat dalam upaya pengembangan usaha lebih lanjut, peserta akan mudah dalam mengakses sumber modal dari lembaga keuangan bank atau non perbankan.

Pelaksanaan program pengabdian tahap ketiga adalah pendampingan. Pendampingan terhadap peserta karang taruna dilakukan setelah pelatihan pengolahan ikan (abon ikan), pemasaran dan tertib adminsitrasi keuangan dilakukan. Secara periodik, sebulan sekali,tim pengabdi mengunjungi lokasi pengurus karang taruna agar semangat wirausaha yang telah tumbuh berlanjut dalam tahap eksekusi.

Dalam pendampingan yang dilakukan selama 3 bulan berturut-turut, akhirnya muncul 1 (satu) dari 10 peserta telah mengembangkan usaha olahan (abon) ikan dan telah mendaftarkan produknya agar memperoleh sertifikat Penyuluhan Industri Rumah Tangga (P-IRT) ke Dinas Kesehatan Kabupaten Gresik sebagaimana Gambar 6;
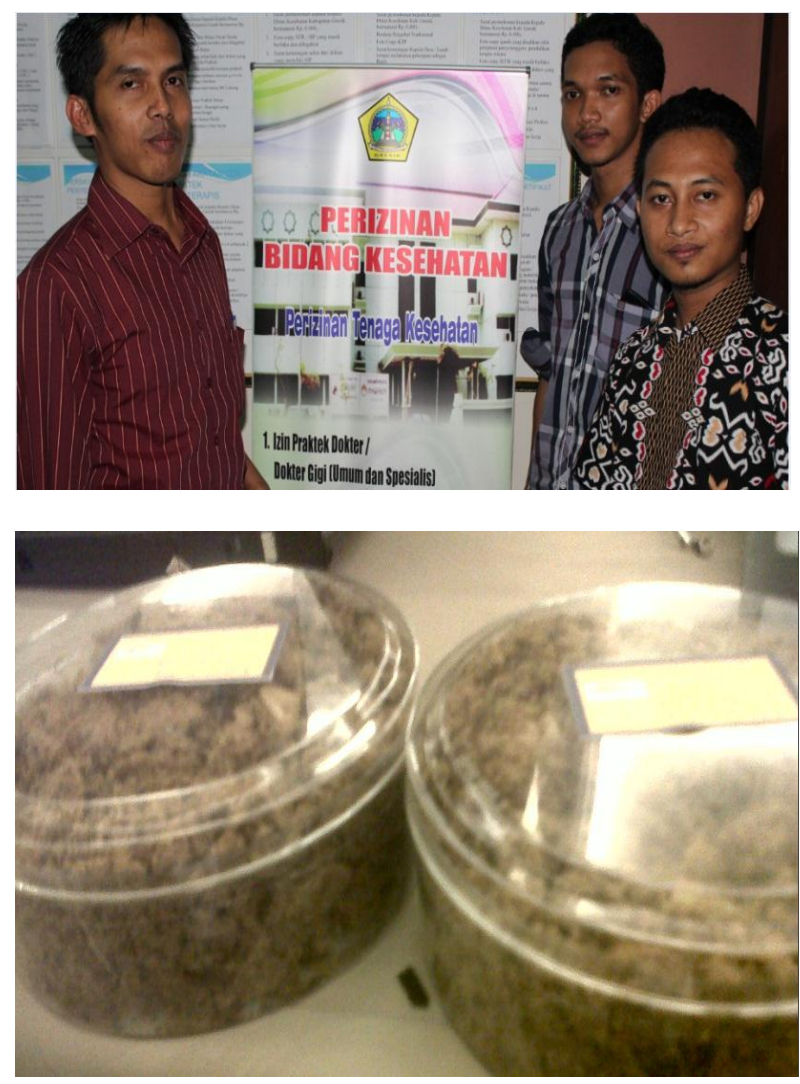

Gambar 6. Pendaftaran P-IRT ke Dinas Kesehatan Kabupaten Gresik

\section{KESIMPULAN}

Permasalahan prioritas mitra, para pengurus karang taruna yaitu rendahnya motivasi berwirausaha dari kalangan pemuda dan para petani yang 
belum berpikir menciptakan nilai tambah atas produk yang dihasilkan. Serangkaian program yang telah dilakukan guna membangun mindset wirausaha dan pada akhirnya muncul keberanian peserta untuk memulai mengembangkan usaha baru, merupakan awalan penting guna menjadi stimulus bagi pemuda lain di desa sebagai bentuk pelopor penciptaan nilai tambah dari potensi lokal desa yakni para petani tambak ikan.

Tim program pengabdian masyarakat menyadari luaran yang dihasilkan masih belum optimal, mengingat persentasi kuantitas peserta dan jumlah yang melakukan start-up business masih 1:10. Tim pengabdi menyarankan agar proses screening peserta untuk program sejenis kedepan bisa dilakukan lebih mendalam serta program pengabdian ini dapat dikembangkan menjadi salah satu model dalam upaya pengembangan wirausaha pemuda khususnya di Kabupaten Gresik dan wilayah lainnya.

\section{UCAPAN TERIMA KASIH}

Ucapan Terima Kasih tim pengabdi sampaikan kepada Direktorat Riset dan Pengabdian Masyarakat Kementerian Riset, Teknologi dan Pendidikan Tinggi atas kepercayaan dan dukungan pendanaan guna menjalankan program pengabdian masyarakat tahun 2015. Terima kasih juga kami sampaikan atas kerjasama yang baik dengan pengurus karang taruna Glanggang dan Gadukan serta aparat pemerintah daerah khususnya Desa Glanggang.

\section{DAFTAR PUSTAKA}

Badan Pusat Statistik, Pengangguran Pemuda Mencemaskan, 24 Maret 2013 http://bisnismanajemen.co.id.

Badan Pusat Statistik Kabupaten Gresik, Kecamatan Duduksampeyan Dalam Angka 2012, http:// gresikkab.go.id

Deputi Kepala Perwakilan Bidang Sistem Pembayaran dan Manajemen Intern Bank Indonesia (BI) Perwakilan Malang, Remitansi TKI Malang Turun 20,8 Persen, 2 Pebruari 2014, http://www.antarajatim.com

Dinas Tenaga Kerja dan Transmigrasi (Disnakertrans) Kabupaten Gresik, Pengangguran Di Gresik Meningkat, 6 September 2013 http:// www.beritametro.co.id.

Peraturan Gubernur Nomor 78 Tahun 2013 tentang Upah Minimum Kabupaten/Kota di Jawa Timur 2014 tertanggal 20 November 2013, http://www.antarajatim.com, 20 November 2013. 